\section{GOVERNMENT INTERVENTION \\ IN RURAL LABOUR MARKET AND \\ ITS IMPLICATIONS FOR WOMEN: \\ HOW MGNREGA MADE WOMEN \\ ECONOMICALLY WELL-OFF}

Abhishek*

\begin{abstract}
Increasing rural real wages can be said to be the best policy of making women economically well-off, as trend across Asia shows higher female labour force participation in rural areas than that of urban areas. The stagnant rural wages impact the women most as they constitute the least paid section of the rural workforce, preferred in the activities which are labour-intensive but lower paid (Veneteshwaralu and Jacob, 2012), and they experience occupational segregation and lower pay in same work compared to men $(A D B, 2016)$. Being the least educated, the women don't have enough opportunity outside agriculture; so, they cannot think of having jobs in more productive sectors and are less free to migrate to the cities because of the social system. The paper looks at the overall employment scenario in India post-liberalisation, and explains the rural labour market and the wage discrimination based on gender. Taking MGNREGA as a case study, the paper attempts to explain how employment generation programmes can contribute to increasing women's participation.
\end{abstract}

Keywords: Rural Labour Market, Wages, Employment, Women Employment, MGNREGA.

"Power is the capacity of social agents, agencies and institutions to maintain or transform their environment, social or physical" (Held, 2015, 1) and the best way to provide someone these capacities can be to engage in a productive, paid and decent work. As engaging in a productive paid work not only provide them money but enhances skills and make a person more capable. In the case of beneficiary being a woman, the provided economic autonomy, boosts confidence - something which she lacks in a patriarchal society, give her opportunities for social interaction and makes the way for the

${ }^{1}$ Centre for European Studies, School of International Studies, Jawaharlal Nehru University, New Delhi - 67. 
constructive participation in decision-making as the economic self-reliance or independence is "a critical factor towards individual autonomy, voice and agency in households and the community", notes the Human Development Report of 2015, a flagship report of UNDP (HDR $2015,110)$. The next year's report subtitled 'Human Development for Everyone' marks that without including women, who constitute the half of the humanity in the process of enjoying human development, we will not be able to universalise the development. The report once again highlights the fact that "gender equality and women's empowerment are fundamental dimensions of human development" (HDR 2016, 12).

But, even while the global think tanks, organisations, economists and policymakers are constantly advocating gender equality and women empowerment, sizable gender gaps remain, especially for the poor women belonging to the rural areas of the developing countries. These disparities increase when poverty combines with other forms of exclusion, such as remoteness, ethnicity, and disability" (HDR 2012, 21). In terms of regions, the largest gap between male-female human development exists in the South Asia where female labour force participation, in 2013, was 30.5 per cent (ILO 2014) and "the HDI value for women is 17.8 per cent lower than the HDI value for men" (HDR 2016, 54). India is not just the largest economy of the region but also one of the countries that find their place among the fastest growing - engines of growth
- economies of the world. In the first decade of new millennium when India witnessed a robust growth in its gross domestic product (GDP), overall wages along with income rose, female participation rate which was 34.1 per cent in 1999-00, witnessed a decrease of almost 7 per cent, when in 2011-12 it remained just 27.2 per cent (ILO. 2014). There is a number of evidence proving that higher female labour force participation can be achieved with the proper policies and this can substantively increase economic growth also (ADB, 2016, 5).

Of all the women, the most deprived lot constitutes of those who live in rural areas and belong to the marginalised sections. These mostly uneducated, unskilled, landless women find employment only as agricultural casual labourers. They are the victims of not only of the historical marginalisation but also of shrinking overall employment opportunities since reforms. The paper argues that if the wages in rural areas remain low it is due to the lack of opportunities in general, and for the women in particular. The State interventions in job creations can not only increase the opportunities but can also set a new wage floor in the rural areas which in turn can further help in poverty alleviation. As we have seen in the case of MGNREGA, the group which gets benefitted most by rising rural wages constitutes of the women in general, and from marginalised sections in particular as it is the women from marginalised sections who are more likely to be employed as casual wage labourers. Rising rural wages can increase 
even the women enrollment rates because the families, when become better-off, are more likely to send their girl child to schools than to the work as casual labour. It can also give more say in the decision makings inside the house.

The paper tries to look into the impacts of MGNREGA in providing employment opportunities with a better wage. For doing the same, we use data collected by different national and international agencies. In the first section, the paper tries to develop an understanding of rural labour market with special attention to those working as casual labourers in the farm sector, landholding pattern and the ways in which the pattern of land-holding impacts the demand and supply of labourers. It also takes a note of falling per worker income agriculture in comparison to the non-agricultural sector. Then the second part in an order to make a holistic understanding, examines the overall employment scenario in India, especially the rising intensity of skill and technology in various sectors and decreasing job-intensity of growth during the postliberalisation period. It also highlights the fact that how, in India, the expected Lewisian turn failed to happen. The next part looks into the role of gender in the rural labour market. We take MGNRGA as an example to understand the impacts which government intervention can make in the rural labour market and its implications for the women, in the fourth part.

\section{The Rural Labour Market}

India still remains a "country of villages" with approximately 70 per cent of the population as well as household- the 69 per cent of the households and 71 per cent of the total population - belonging to rural areas. But, in terms of earning, rural areas are far behind the urban ones, as a person working as casual labour in work other than public work, in a rural area earns ₹138.62 per day, whereas for his urban counterpart it is ₹170.1 per day. Even in the case of a regular salaried person, the average daily wage of a regular wage/ salaried employee in the rural areas is ₹298.96 per day as compared to ₹ 449.65 per day in the urban areas (NSSO, $68^{\text {th }}$ round). Agriculture still continues to be the mainstay of villages, but from earning point of view, the conditions are worse if the person is employed in agriculture - it is not only that per worker income is least in the agriculture, the gap is increasing every year (Table 1). This happens because of two reasons. First, rural labour markets are not free markets; there exist various social restrictions, on the movement of labour. However, these restrictions are waning away and the practices like that of forced and attached labours are not so common as they use to have in past decades, but, the restrictions related to caste and gender still remains (Thorat et al., 2003, Thorat, 2008). And secondly, most of the agricultural workers are illiterate or educated up to the primary level; they are unskilled for anything other than agriculture and Indian economy failed to create enough employment opportunities for them outside agriculture. 
Table 1: Per Worker Income in Agriculture and Non-agriculture Sectors in India (1993-94 Prices)

\begin{tabular}{|c|c|c|c|c|c|c|}
\hline \multirow[b]{2}{*}{ Period } & \multirow{2}{*}{$\begin{array}{l}\text { Agri- } \\
\text { cul- } \\
\text { ture }\end{array}$} & \multirow{2}{*}{$\begin{array}{c}\text { Non- } \\
\text { agriculture }\end{array}$} & \multirow{2}{*}{$\begin{array}{l}\text { Ratio of non- } \\
\text { agriculture } \\
\text { to agri- } \\
\text { culture }\end{array}$} & \multicolumn{3}{|c|}{ Growth rates } \\
\hline & & & & $\begin{array}{l}\text { Agri- } \\
\text { cultural }\end{array}$ & $\begin{array}{l}\text { Non-agri- } \\
\text { cultural }\end{array}$ & $\begin{array}{l}\text { Ratio of non- } \\
\text { agriculture to } \\
\text { agriculture* }\end{array}$ \\
\hline $\begin{array}{l}1978-79 \text { to } \\
1983-84\end{array}$ & 9961 & 28,430 & 2.85 & & & \\
\hline $\begin{array}{l}1988-89 \text { to } \\
1993-94\end{array}$ & 11,179 & 39,355 & 3.52 & 1.16 & 3.31 & 2.85 \\
\hline $\begin{array}{l}1998-99 \text { to } \\
2003-04\end{array}$ & 11,496 & 59,961 & 5.22 & 0.28 & 4.30 & 15.35 \\
\hline
\end{tabular}

Source: Uma Kapila (2013) * Calculated by the author.

Agricultural wages have always been low because there has always been a big reserve army of labourers. The people who work as an agricultural labourer consists of not only those who are landless but also of those who own the land but their land is not sufficient for their subsistence, so they also work as the wage labourer to fulfil their needs (Table 2). The parentage distribution of all the rural households on the basis of size of land they are cultivating revealed that at all-India level about 2 per cent of households were landless and around 63 per cent were marginal farmers possessing cultivated land between 0.01 and 0.4 hectares, only 2.1 per cent of household possessed cultivated land above 2.01 hectares (NSSO $61^{\text {st }}$ round). Out of the total holdings, 46.75 per cent are of less than .5 hectares and 67.01 per cent are marginal holdings (up to 1 hectare).

Considering the landholding pattern in the light of social category, i.e. caste, we witnessed that a large number of the smallholdings belong to the people from historically marginalised groups, who are at the lowest rung of the society. Fourteen per cent of the total holding below .5 hectare belongs to the scheduled castes and five per cent belongs to the scheduled tribes. Now, if we consider the total percentage in terms of marginal holding, it is again around fourteen per cent for scheduled castes and around seven per cent for the scheduled tribes. Whereas, if we consider large holdings (more than 10 hectares), only 5.37 per cent belongs to the scheduled castes and 11 per cent belongs to scheduled tribes. So, the contrast in the case of scheduled caste is clearly visible from these data itself. But actually, this data hide much than what it reveal; it is because the landholding about which it talks does not mean the land owned. It is about operational holdings which mean that it includes along 
with wholly-owned \& self-operated holdings many other categories which are "partly owned \& partly leased-in holdings, wholly leased-in holdings, wholly otherwise operated holdings, partly-owned \& partly otherwise operated holdings, partly leased-in \&partly otherwise operated holdings and partly owned, partly leased-in and partly otherwise operated holdings" also. Actually, it is a rising practice in the rural areas to lease out or give the lands to be operated by some other person - who normally is one from marginalised sections (Corta and Venkateshwarlu, 1999). According to the Rural Labour Enquiry Report on General Characteristics of Rural Labour Households
2004-05 at the national level, majority of the Rural Land-holding Households (RLHs) and the Agricultural Labour Households (ALHs) owned insignificant cultivated land. Only 30.47 per cent of the RLHs and 31.27 per cent of the ALHs were reported to be in possession of cultivated land (Gol 2011, 17). What comes out from the discussion are firstly, most of the holdings are small-holdings; secondly, even it is correct that a large number of holdings are being operated by the marginalised sections it is not that they are being owned also; and, third, most of the wage labourers - be the landless one or one with holding insufficient to support their family - are from the marginalised section.

Table 2: Estimated Number and Area of Operational Holdings by Size Classes, 2010-11

\begin{tabular}{|c|c|c|c|}
\hline Serial No. & Size (hectares) & Number of holdings & Area covered \\
\hline 1 & Below .5 & $64678854(48125)$ & 15441213.43 \\
\hline 2 & $.5-1.0$ & $28147125(23054)$ & 20467051.06 \\
\hline 3 & $1.0-2.0$ & $24779150(21643)$ & 35244061.41 \\
\hline 4 & $2.0-3.0$ & $9648724(9629)$ & 23164312.98 \\
\hline 5 & $3.0-4.0$ & $4246828(4632)$ & 14540475.63 \\
\hline 6 & $4.0-5.0$ & $2431011(2809)$ & 10761878.20 \\
\hline 7 & $5.0-7.5$ & $2510782(3028)$ & 15129164.92 \\
\hline 8 & $7.5-10-$. & $9334224(1255)$ & 7936865.19 \\
\hline 9 & $10.0-20.0$ & $799030(1142)$ & 10488783.26 \\
\hline 10 & Above 20.0 & $173733(262)$ & 6418048.80 \\
\hline 11 & All Classes & $138348461(115580)$ & 159591854.88 \\
\hline
\end{tabular}

Number in () indicates data of Agricultural Survey, 1995-96 Numbers in () are in,000 units Source: Agriculture Census, 2010-11. 


\section{Agricultural Workers in the Pre-reform Period}

In the initial periods post-Independence, the demand of workers increased because of the increase in the land use under net sown area, the trend which continued up to the decade of the 1980s (Table 3). This was the period in which Indian farmers were simply replicating their old ways of labour-intensive farming - primitive tools, traditional crops, indigenous seeds - to the new areas. Green revolution, which drastically changed the Indian rural economy, helped the wage labourers much only during the initial phases when the real wages were stagnant, despite a substantial increase in demand for the labourer. In these situations, the least cost combination was highly labour observing (Bhalla, 1999, 38).

The situation started changing in the later periods when not only the big farmers started implementing labour-saving technologies in the agriculture but the government also played an important role in it by offering subsidies on farming machines. When agricultural jobs declined, a large number of farm labourers started searching for opportunities in rural nonfarm sectors. Vaidyanathan (1986) highlighted this phenomenon of distressed migration outside agriculture in as early as 1983 itself. He argued that where agriculture was unable to provide employment, non-farm sector played a crucial role in absorbing the surplus labour, and "rural workers who cannot get adequate work in agriculture spill over into rural nonagricultural activities so that the later act .....as a sponge for the excess labour". He further said that "the higher the rate of unemployment, the higher is likely to be the share of the nonagricultural sector in total rural employment and the lower the non-agricultural wage relative to that in agriculture." Pushing out workers from the agriculture without being enough opportunities in non-agricultural sectors continued, the reserve army of labour expanded further depressing the wages.

\section{Post-reform Scenario}

Reforms came to India with the promise of creating new job opportunities for all. The argument at the time was that the multinational corporations (MNCs), in order to gain

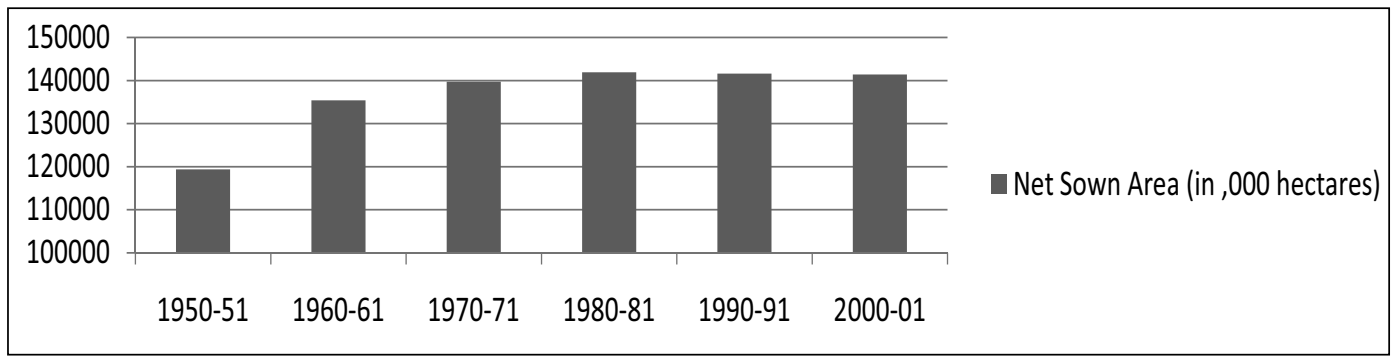

Figure 1: Net Sown Area (from 1950-51 to 2000-01) 
profit from the lower wages of global south, will shift their labour-intensive components from developed north, creating job opportunities in the labour-surplus underdeveloped countries, and the opening of the markets will help the co India untry to solve the problem of unemployment.

But it never happened because India was not just a labour-surplus country; it was an unskilled-labour-surplus country, with very low literacy and education level. There was just a small number of highly skilled workers qualified enough to work with complex technologies so what India attracted was not the labour-intensive but technology-intensive manufacturing, for example, automobile. Other than our education structure, the inverted duty structure also played an important role in keeping manufacturing away from India. The skill-intensity of Indian manufacturing increased; its share in GDP remained almost stagnant. The success came in the service sector, in works like BPO and KPO, Indian workforce equipped with the English language succeeded in a great manner. But this advantage was much limited to the urban English-educated youth, not for those who were migrating outside agriculture. The overall situation pushed rural workers, especially the uneducated one (Table 4), into an even more disadvantageous position. The rural-urban divide rose drastically and the incidence of poverty in the post-reform period for agricultural labourers increased from 42.62 per cent in 1993- 94 to 46.01 per cent in 199900 (Sharma H.R.).

Table 3: Education of Rural Workers: 1999-00 to 2011-12

(Usual Principal and Subsidiary Status, UPSS)

\begin{tabular}{|l|c|c|c|c|c|c|}
\hline & \multicolumn{3}{|c|}{ Male } & \multicolumn{3}{c|}{ Female } \\
\cline { 2 - 7 } & $\mathbf{1 9 9 9 - 0 0}$ & $\mathbf{2 0 0 4 - 0 5}$ & $\mathbf{2 0 1 1 - 1 2}$ & $\mathbf{1 9 9 9 - 0 0}$ & $\mathbf{2 0 0 4 - 0 5}$ & $\mathbf{2 0 1 1 - 1 2}$ \\
\hline Not literate & 39.6 & 33.8 & 28.0 & 73.9 & 66.4 & 56.3 \\
\hline Literate \& up to primary & 27.3 & 29.4 & 27.6 & 15.5 & 18.4 & 21.8 \\
\hline Middle & 16.3 & 18.1 & 19.0 & 6.2 & 8.7 & 10.8 \\
\hline Secondary & 9.3 & 9.3 & 12.9 & 2.8 & 3.6 & 5.9 \\
\hline Higher secondary & 4.2 & 4.6 & 6.6 & 0.9 & 1.4 & 2.6 \\
\hline Diploma/certificate & -- & 1.0 & 1.1 & -- & 0.5 & 0.5 \\
\hline Graduate \& above & 3.3 & 3.8 & 5.0 & 0.6 & 0.9 & 2.1 \\
\hline All & 100 & 100 & 100 & 100 & 100 & 100 \\
\hline
\end{tabular}




\section{Employment Scenario in India, Post- Liberalisation}

Since the last two-and-a-half decades after the reforms, while India succeeded in considerably increasing the rate of GDP growth, it failed to achieve similar success in generating employment and sharing the generated wealth. The rate of employment generation was two per cent during the previous three decades, despite GDP growth rate being modest 3.5 per cent. Just after the reforms, contrary to what argued, growth of employment in the organised sector fell to 0.53 per cent during 1994-2000, the same during the period 1983-94 was 1.20 per cent, even the overall growth of employment also fell to be around one per cent during 1993-2000 (Sharma 2007). Even while the unemployment rate in India since reforms, has always been less than 4.5 (Table4), most of the jobs have been in the informal sector only. More than 90 per cent of the employments are in the informal sector. According to NSSO $68^{\text {th }}$ round survey, around three-fourth (72 per cent) of the workers in AGEGC and non-agriculture sectors are employed in the informal sector. In terms of the urban-rural divide, the informality is more pronounced in the rural areas ( 75 per cent) than the urban areas (69 per cent). Due to the "utilization of contract and other forms of casual labour", share of those who are without any social security, is rising well in the organised sector also (ILO, 2015).

Another significant point in the Indian growth story has been of the almost stagnant share of manufacturing, both in employment as well as GDP. Instead of transition from agriculture to manufacturing and then services, Indian trajectory has been of agriculture to services (Table 5). In the first five years of the new millennium, there has been an addition of nearly 12 million employments in the manufacturing sector followed by a decline of 5 million in the next five-years. By contrast, employment in services had grown by 18 million between 2000 and 2005 (Mehrotra et al., 2012). The share of tertiary

Table 4: Unemployment Rate (Percentage of the Total Labour Force, Modelled ILO Estimate)

\begin{tabular}{|l|c|c|c|c|c|c|c|c|}
\hline Year & 1991 & 1992 & 1993 & 1994 & 1995 & 1996 & 1997 & 1998 \\
\hline Percent & 4.1 & 4.1 & 4.3 & 3.7 & 4.0 & 4.0 & 4.4 & 3.8 \\
\hline Year & 1999 & 2000 & 2001 & 2002 & 2003 & 2004 & 2005 & 2006 \\
\hline Percent & 4.2 & 4.3 & 4.0 & 4.3 & 3.9 & 3.9 & 4.4 & 4.3 \\
\hline Year & 2007 & 2008 & 2009 & 2010 & 2011 & 20122 & 2013 & 2014 \\
\hline Percent & 3.7 & 4.1 & 3.9 & 3.6 & 3.7 & 3.7 & 3.6 & 3.5 \\
\hline
\end{tabular}

Source: World Bank, Data Bank. 
sector which was less than half, 49 per cent in 1991 rose to be around two-third in just twodecades. The service sector, contributing well over 65 per cent of incremental growth, has been the main driver of India's GDP growth. The decreasing share of manufacturing in employment is not a case special to India only, falling employment intensity of manufacturing is a global phenomenon and the late-industrialising countries cannot expect to replicate the success of the early industrialisers (Rodrik, 2015). In China (2005), the share of manufacturing was 32.5 per cent in GDP but only 15.9 per cent in employment, whereas in Thailand (2007), it was 35.6per cent in GDP but only 15.1 per cent in employment. Compare it with Japan where in 1970, the share of manufacturing was 36.0 per cent in GDP and 27.0 per cent in employment or Taiwan in 1990 , the share of manufacturing was 33.3 per cent in GDP and 32.0 per cent in employment (Dev 2016; Ghose 2015).

During the period 1983-94, unemployment rate on current daily status decreased significantly, both for the male as well as female. Over the longer period, i.e. from 1983 to 2004-05, there was a small decline in unemployment in urban areas, but the decrease was hardly adequate to the worsening rural conditions. During the period 2004-05 to 2009-10, the unemployment rate for male in rural areas decreased to 6.4 per cent from that of 8 per cent. For the female, the corresponding figures were 8.1 and 8.7, respectively, unemployment rates declined in urban areas also. Jha attributes this decline in the unemployment rate "more to the decline in labour force participation rate due to inadequacy of job creation and 'discouraged worker effect' (ILO, 2017).

Table 5: Share of Manufacturing in Employment and GDP

\begin{tabular}{|l|c|c|}
\hline \multicolumn{1}{|c|}{ Year } & $\begin{array}{c}\text { Share of manufacturing in total } \\
\text { employment }\end{array}$ & $\begin{array}{c}\text { Share of manufacturing in total } \\
\text { GDP }\end{array}$ \\
\hline 1983 & 10.6 & 14.7 \\
\hline $1987-88$ & 11.2 & 15.0 \\
\hline $1993-94$ & 10.5 & 14.6 \\
\hline $1999-2000$ & 11 & 15.1 \\
\hline $2004-05$ & 12.2 & 15.3 \\
\hline $2009-10$ & 11.4 & 16.2 \\
\hline $2011-12$ & 12.6 & 16.3 \\
\hline
\end{tabular}

Source: ILO, 2017. 


\section{Agricultural Workers in Post-reform Period}

As we have noted in the very start of the paper, Indian villages are characterised by a large number of households operating smallholdings (Table 7). Families with small holdings work on their farm manually with the help of family labour. If at one hand this rising fragmentation is one of the reasons for falling employment opportunities in agriculture, on the other the large holdings - as they facilitate the adoption of labour saving technologies and increasing concentration of landholdings in the few hands in a way indirectly contributes to the decline in overall labour absorption (Table 8) by not only reducing the level of selfemployment butalso that of wage employment which could have been generated in the case of comparatively equitable landholding. The traditional settings of the rural system were that the households with smaller holding use not only to work on their own land but, supplemented their income by working on the farms of big landholders.

But the focus on mechanisation changed it all. With the mechanisation of farming, the unskilled works got transferred to machines. Now, large landowners with enough capital found it profitable to replace the labour with that of technology and tend to do so up to a larger extent. As Rawal and Saha (forthcoming) noted, "greater adoption of labour displacing technology (in particular, increasing use of machines and weedicides), caused by increasing concentration of landholdings and increasing cost advantage of using labour displacing techniques among other factors, is likely to have been an important factor behind the decline in overall level of labour absorption

Table 6: Percentage Distribution of Rural Households, by Size Class of Operational Holding

\begin{tabular}{|l|c|c|}
\hline Land Size Class $\mathbf{( H a )}$ & $\mathbf{2 0 0 2 - 0 3}$ & $\mathbf{2 0 1 2 - 1 3}$ \\
\hline Landless & 39.7 & 37.7 \\
\hline 0.001 - Less than 1 & 40.8 & 47.2 \\
\hline 1 - Less than 2 & 10.5 & 8.9 \\
\hline 2 - Less than 3 & 4.3 & 3.2 \\
\hline 3 - Less than 5 & 2.7 & 1.9 \\
\hline 5 - Less than 10 & 1.5 & 0.9 \\
\hline 10 and Above & 0.5 & 0.2 \\
\hline All Size Classes & 100.0 & 100.0 \\
\hline
\end{tabular}

Source: Calculated from AIDIS, NSSO (2002-03 and 2012-13). 


\section{Table 7: Percentage Distribution of Area Operated by Rural Households, by Size Class of Operational Holding}

\begin{tabular}{|l|l|l|}
\hline Land Size Class $\mathbf{( H a )}$ & $\mathbf{2 0 0 2 - 0 3}$ & $\mathbf{2 0 1 2 - 1 3}$ \\
\hline Landless & 0.0 & 0.0 \\
\hline 0.001 - Less than 1 & 24.1 & 32.6 \\
\hline 1 - Less than 2 & 21.5 & 22.5 \\
\hline 2 - Less than 3 & 15.1 & 13.9 \\
\hline 3 - Less than 5 & 15.7 & 15.7 \\
\hline 5 - Less than 10 & 14.9 & 10.9 \\
\hline 10 and Above & 8.7 & 6.7 \\
\hline All Size Classes & 100.0 & 100.0 \\
\hline
\end{tabular}

Source: Calculated from AIDIS, NSSO (2002-03 and 2012-13).

in agriculture." Despite the slowdown in the agricultural sector, the market for the tractor remained unaffected; its production, as well as the sale, continued. As Sarkar (2013) notes, "Indian agricultural sector has a higher density of four-wheel tractors than other less developed countries and India is also one of the largest manufacturers of tractors in the world."

The workers migrated outside agriculture because of the "push" of technological change in agriculture (Fei and Ranis, 1975) limiting the labour absorption, the movement of excess workers from the agriculture sector was directed not only towards the cities - a large number of erstwhile agricultural labourers migrated to cities in search of jobs- but also to the other sectors in the rural area itself meaning that even those who remained in rural areas, changed their sector (Table 9). The real farm wages have increased by 3.7 per cent per annum during the 1990s, compared to next decade's, i.e., 2000s, 2.1 per cent per annum. In the pre-NREGA period of the 2000s rise in the real farm wages was only 1.8 per cent per annum. The compound growth rates of real rural wages were negative in the first half of the 2000s (Table 10). This trend of stagnation in the real wage rate in rural India got broken only after the introduction of MGNREGA. These poor and the illiterate who were primarily employed in casual wage employment in agriculture had lower reservation wages (Saha and Verick, 2016) and were likely to show "greatest inclination to become involved in non-farm activities" (Lanjouw and Shariff, 2004). 
Table 8: Percentage of Rural Workers, by Sector and Gender (15 years and above), Principal Status

\begin{tabular}{|l|c|c|c|c|}
\hline \multirow{2}{*}{\multicolumn{1}{|c|}{ Sector }} & \multicolumn{2}{c|}{ Male } & \multicolumn{2}{c|}{ Female } \\
\cline { 2 - 5 } & $\mathbf{1 9 9 9 - 2 0 0 0}$ & $\mathbf{2 0 1 1 - 1 2}$ & $\mathbf{1 9 9 9 - 2 0 0 0}$ & $\mathbf{2 0 1 1 - 1 2}$ \\
\hline Manufacturing & 70.3 & 73.5 & 29.7 & 26.5 \\
\hline Construction & 89.5 & 89.1 & 10.5 & 10.9 \\
\hline Other Non-manufacturing & 85.5 & 85.5 & 14.5 & 14.5 \\
\hline Services & 85.2 & 85.1 & 14.8 & 14.9 \\
\hline All Non-Farm Sector & 81.5 & 83.7 & 18.5 & 16.3 \\
\hline Agriculture and allied activities & 66.9 & 71.8 & 33.1 & 28.2 \\
\hline
\end{tabular}

Source: Saha and Verick, 2016.

Table 9: Compound Growth Rate in Real Rural Wages (in per cent)

\begin{tabular}{|l|c|c|c|c|c|c|c|}
\hline \multirow{2}{*}{ Year } & \multicolumn{3}{|c|}{ Agricultural Wages } & $\begin{array}{c}\text { Non-ag- } \\
\text { ricultural } \\
\text { Wages }\end{array}$ & \multicolumn{3}{c|}{ Unskilled Workers } \\
& Male & Female & Persons & Male & Male & Female & Persons \\
\cline { 2 - 8 } & 0.08 & -0.81 & -0.29 & -0.90 & -0.81 & -1.62 & -1.16 \\
\hline $1999-2000$ to $2005-06$ & 4.34 & 5.80 & 4.96 & 3.03 & 5.27 & 5.62 & 5.42 \\
\hline $2005-06$ to 2011-12 & 4.34 & 1.05 & 2.19 & 1.93 & 2.08 \\
\hline $1999-2000$ to 2011-12 & 2.19 & 2.44 & 2.30 & & & &
\end{tabular}

Source: Chand and Srivastava.

The changes started coming after the introduction of MGNREGA when it not only created employment opportunities but also a wage floor. Employment under MGNREGA at the end of the first decade of the 2000s during 2009-10 reached 13 per cent of the total scope for employment under it; the same corresponds to about 3 per cent of the rural labour households' labour supply (Chand and Srivastava). The Paris School of Economics, in its study in 2011, concluded that due to the overall impacts on the wage rates MGNREGA is even beneficial to the non-participating households also. According to JP Morgan, Post-MGNREGA, average wage increments were almost touched two-digit when it reached 9.7 per cent between the year of 2006 and 2009. And between January 2010 and May 2011, annual wage growth averaged almost 18.8 per cent. Since January 2010, agricultural rural wages increased 16.7 per cent on a yearly average. Wage growth for men in the agricultural sector was 19.7 per cent on yearly average while for women it is 20.8 per cent" on yearly average (JP Morgan, 2011). 
Table 10 : India's Female Economic Participation and Opportunity Index

\begin{tabular}{|c|c|c|c|}
\hline Year & Score & Rank & $\begin{array}{c}\text { Number of } \\
\text { countries }\end{array}$ \\
\hline 2006 & 397 & 110 & 115 \\
\hline 2007 & 398 & 122 & 128 \\
\hline 2008 & 399 & 125 & 130 \\
\hline 2009 & 412 & 127 & 134 \\
\hline 2010 & 403 & 128 & 134 \\
\hline 2011 & 396 & 131 & 135 \\
\hline 2012 & 459 & 123 & 135 \\
\hline 2013 & 446 & 124 & 136 \\
\hline 2014 & 410 & 134 & 142 \\
\hline 2015 & 383 & 139 & 145 \\
\hline
\end{tabular}

Source: Global Gender Gap Report, 2015.

MGNREGA helped the rural wage labours in general - by adding to the opportunities available, tightening the rural labour market, increasing reservation wages - and women wage labourers in particular as for it was not a guarantee of job, but a job with a better working condition and wages - equal to that of the male counterparts - many times higher than the previous one.

\section{Gender in Rural Labour Market}

"The Indian labour market is notoriously unfriendly to women" (Papola, 2012). In terms of female economic participation and opportunities, India is not only one of the countries doing bad enough but a country where the situation is not improving even. In 2006, the year MGNREGA was introduced, India, with a score of 0.397 ranked 110 out of
115 countries in economic participation and opportunity index. In 2015, India's score was 0.383 and it ranked 139 out of 145 countries (Table 11).

\section{Table 11: Male and Female Labour Force Participation Rate according to Usual Status in Rural and Urban Areas, aged 15 years and above}

\begin{tabular}{|c|c|c|c|c|}
\hline \multirow{2}{*}{ Year } & \multicolumn{2}{|c|}{ Rural } & \multicolumn{2}{c|}{ Urban } \\
\cline { 2 - 5 } & Male & Female & Male & Female \\
\hline $1993-94$ & 87.6 & 49.1 & 80.1 & 23.8 \\
\hline $1999-00$ & 84.5 & 36.4 & 78.2 & 18.0 \\
\hline $2004-05$ & 86.4 & 49.7 & 79.6 & 24.6 \\
\hline $2009-10$ & 82.5 & 37.8 & 76.2 & 19.4 \\
\hline $2011-12$ & 81.3 & 35.8 & 76.4 & 20.5 \\
\hline
\end{tabular}

Source: NSSO various rounds.

In India, the female labour force participation is more in rural areas - where most women work as an agricultural labourer - than the urban areas (Table 12). In rural India, "labour force participation rate for women in 2004-05 was 36.6 per cent as compared to 22.3 per cent for urban women but at the same time, more than $4 / 5^{\text {th }}$ of all women working in rural areas were engaged in agriculture (83.3 per cent, 106 million), which is the least productive sector in India and characterised by widespread poverty" (NSSO). As far as wage discrimination is concerned, according to NSSO $68^{\text {th }}$ round, a rural male working as a casual worker, in a work other than public work, gets ₹149.32 whereas the female gets only ₹103.28. One thing worth noting here is that these figures are of the post-MGNREGA period. 
So, a woman agricultural worker not only faces the challenge of irregular employment, lower wages and condition of works putting an excessive burden (Padhi, 2007) but also the gender discrimination. In the total picture, women not only engage themselves mostly in unpaid economic activities inside the home, even outside they participate sometimes as a 'volunteer'. It is not that they don't want to work, but most prefer working in the premises of the home. Of the women engaged in domestic duties, exactly one-third of females (33 per cent) aged 15 years or more in rural areas and 27 per cent of those living in urban areas were willing to accept work opportunities but in the premises of the household (NSSO Report, 550).

During the longer period, employments for female in the non-farm sector, which was 11.7 million in 1983, gradually increased to 21.6 million in 2009-10. Even in the farm sector, their numbers increased from 76.6 million in 1983 to 103.2 million in 2004-05, after which we see that in next five-years period ending in 200910 , the number of female workers "declined to the tune of 20.3 million in farm sector of rural India" (Das, 2012). The period after 2004-05 has been of increasing opportunities and rising rural wages, so the decline in rural female LFPR in this phase goes contrary to the discouraged worker effect' which argues that usually what happens that prolonged unavailability of employment, falling wages push the workers outside the labour market by discouraging them.
The fact of female labour force participation in India is that discouraged worker effect may have been present but it is certainly not the reason why women choose to remain outside the labour force. When household incomes increase and families do not find it necessary that its womenfolk also contribute monetarily to the household women tend to drop out of the labour force (Lahoti and Swaminathan, 2013). In India, it is not just the opportunity cost, but culture becomes an important factor in a woman's decision to work or not. Even for those chose to work, the same factor influences on picking the job or sector. For example, as Mahapatro (2017) argues that "the choice of employment sector for women in Indian society is also guided by the prescribed traditional domestic roles and gender norm" and if participation of women belonging to other backward castes is more than that of so-called upper castes in formal employment, it is because of the cultural restrictions which a woman from these so-called upper castes face.

The inter-State variations in labour force participation confirm the role of patriarchy. In the States of northern India where societies are more patriarchal, we see lower female participation that stands at 5.7 per cent, 14.5 per cent and 16.3 per cent for Bihar, Haryana and Uttar Pradesh, respectively (Bhattacharya and Deshpande, 2013). Chand and Srivastava note that in the period between 1993-94 and 2009-10, the increase in the rural workforce 
has been mainly due to increase in the number of male workers. Despite 25 per cent increase in the population of females, the number of female workers remained the same, resulting in a decline in the WPR of not only females but of total workers in rural areas. It happened not only because of withdrawing female labour from agriculture due to an improvement in economic conditions but also because of the "big increase in the pursuit of education by rural females", which we have seen above (Chand and Srivastava, 2014).

But, it is not the case that each and every woman is equally prone to leave the labour market in pursuit of education when rising wages make the households comparatively well-off. The decision on a woman leaving/ staying in the job depends on social and economic factors. The women from landless and marginalised families usually don't leave the markets as early as the women from comparatively well-off sections do. The decision that whether a girl will go to the school or join the labour market can also be influenced by the availability of educational institutions nearby. So, with the rising wages, the younger women from comparatively well-off families leaving in areas with better educational facilities will be leaving the labour market for education but not those belonging to marginalised sections and living in areas with least educational facilities.

Whatever the case may be, either women leaving the labour market for education or remaining in the labour market and earning higher wages will result in their empowerment. In the case of education, the more educated women will have greater productivity, as they will be more skilled or can be easily made more skilled. So, when they enter the workforce, they will act as a role model. And, those women who don't leave the labour market and enjoy the benefit of higher/equal wages will certainly have a greater say in the decisions inside the household because of being an equal earning partner.

\section{Mahatma Gandhi National Rural Employment Guarantee Act (MGNREGA)}

The National Employment Guarantee Act (NREGA) was notified on $7^{\text {th }}$ September, 2005. It was renamed as Mahatma Gandhi National Employment Guarantee Act (MGNREGA) on October 20, 2009. The act mandates "to provide a minimum of 100 days of guaranteed wage employment in a financial year (FY) to every rural household whose adult member volunteer to do unskilled work." Along with providing at least 100 days work as per demand resulting in the creation of productive assets of prescribed quality and productivity, the other objectives of the programme include "strengthening the livelihood resource base of the poor, proactively ensuring social inclusion and strengthening the Panchayati Raj Institution (PRIs)" (nrega.nic.in). MGNREGA was unique because of the provision of unemployment allowance that in the case the employment is not provided within 15 days 
of the date from which it was demanded, the person can claim compensation.

The scheme was launched on February 2,2006 , initially only in the country's 200 most backward districts. It was extended afterwards to 330 districts during 2007-2008 and on September 28, 2008, it became an all-India scheme covering all rural areas. MGNREGA was a paradigm shift from earlier schemes. More than an all-India project, it introduced a rights-based framework which ensured a legal guarantee for the employment and time-bound action to fulfil that guarantee. It included demand-based resource availability and accountability of the public delivery system and was not only incentivising the better performing States as the Central government was funding 90 per cent of costs used for generating employment. There were also the disincentives for the non-performers as the unemployment allowance to be paid in order to not providing jobs to the seekers was State liability (Mehrotra, 2009). Due to all these measures, the impacts became visible from the very beginning. A survey conducted in 20 districts out of first 200 districts where the scheme was first launched found that "first, the percentage of households having an annual income less than Rs.5,000 came down from 5.5 per cent to 2.9 per cent and those having annual income between Rs.5,000 and Rs.10,000 came down from 41.5 per cent and 26.6 per cent. Second, beneficiaries earning in the range of Rs.10,000-15,000 and up to
20,000 increased from 33 and 20 per cent to 44 and 26.3 per cent, respectively, as a result of the impact of the scheme. The effect is clearly visible in the eastern region where there is a reduction of low income group up to one-third of the original size. Third, 52.3 per cent of the households are unskilled labourers eking out their livelihood by odd and unskilled jobs. Fourth, 12 per cent are agricultural peasants totally depending on seasonal agricultural works. Most of the households depending on purely unskilled labour activities are hailing from the eastern region" (IAMR).

An analysis by economist and social activist Jean Dreze observes that in the first five years of the new millennium (2000-01 to 2005-06) "growth rate of real agricultural wages was around 0.1 per cent per year for men and negative for women, but after the implementation of MGNREGA (2005-06 to 2010) the growth rate for agricultural wages increased 2.7 per cent per year for men and 3.6 per cent per year for women" (The Hindu, 2013). It happened because for these unskilled workers now it was not only possible to have a job for at least 100 days or unemployment allowance but it was along with a decent payment. The growth rate of women wages was higher because they were getting paid much lower wages in the pre-MGNREGA period. 


\section{The Pre-MGNREGA Situation}

Mehrotra finds that in 14 big States of India, the wages ranged from a lowest of Rs.30.23 in Assam to a highest Rs.60.79 in Tamil Nadu for males. For females, the lowest was just Rs.9.45 in Rajasthan and the highest was Rs.32.35 in West Bengal. All-India average wage was Rs. 61.23 for male and 44.59 for female. These figures discussed here are average wages and the real situation on the land may be even worse or better. For example, the average wages in Uttar Pradesh for male and female were Rs.47.79 and Rs 26.09, respectively, but in Allahabad district of Uttar Pradesh, the local wages were as low as Rs.25 a day (Dreze and Khera, 2009). The highest wage in among northern States was in Haryana, where the male wage rates were Rs.57.83, but in terms of female wages rates, Haryana comes second after Uttar Pradesh where the wage was Rs.26.09, around three rupees more than that of Haryana (Table 11). In none of the States, the wages, in any case, were adequate enough for a person to fulfil the basic needs.

Table 12:

Prevailing Pre-MGNREGA Wages and MGNREGA Wages

\begin{tabular}{|c|l|c|c|c|c|}
\hline \multirow{2}{*}{$\begin{array}{c}\text { S. } \\
\text { No. }\end{array}$} & \multicolumn{1}{|c|}{ State } & Prevailing Wages (In Rs.) & \multicolumn{2}{c|}{ MGNREGA wages (In Rs.) } \\
\cline { 3 - 6 } & & Men & Women & At the time of introduction & Present \\
\hline 1 & Andhra Pradesh & 36.61 & 27.83 & 80.00 & 180 \\
\hline 2 & Assam & 30.23 & 15.52 & 66.00 & 179 \\
\hline 3 & Bihar & 45.06 & 26.24 & 77.00 & 162 \\
\hline 4 & Gujarat & 55.48 & 30.14 & 50.00 & 178 \\
\hline 5 & Haryana & 57.83 & 23.35 & 99.21 & 251 \\
\hline 6 & Karnataka & 49.00 & 27.85 & 74.00 & 204 \\
\hline 7 & Kerala & 55.89 & 27.99 & 125.00 & 229 \\
\hline 8 & Madhya Pradesh & 40.61 & 26.54 & 67.00 & 159 \\
\hline 9 & Maharashtra & 52.97 & 31.90 & 69.00 & 181 \\
\hline 10 & Orissa & 44.86 & 14.02 & 70.00 & 174 \\
\hline 11 & Rajasthan & 44.16 & 9.45 & 73.00 & 173 \\
\hline 12 & Tamil Nadu & 60.79 & 31.23 & 80.00 & 183 \\
\hline 13 & Uttar Pradesh & 47.79 & 26.09 & 100.00 & 167 \\
\hline 14 & West Bengal & 44.58 & 32.35 & 70.00 & 174 \\
\hline & All- India & $\mathbf{6 1 . 2 3}$ & $\mathbf{4 4 . 5 9}$ & & \\
\hline
\end{tabular}

Source: Mehrotra, 2009; Ministry of Rural Development, Government of India, March 31, 2015. 
Other than prevailing low wages, another point to note is the difference between the male and female wage rates. The women labourers getting lower wage is not limited to one or two States or the region but it is an all-India phenomenon and the drop in wages depends upon the local conditions, i.e. availability, nature of work, social norms, etc. The highest wage for the women was in West Bengal (Rs.32.35) which was Rs.12.23 less than the prevailing wage rates for the male workers. In terms of percentage, on an all-India basis, the female wages were 72.82 per cent that of male. In State-wise terms, the female wage ranged from 21.39 per cent to 76.01 per cent of male wages in Rajasthan and Andhra Pradesh, respectively (Table 14).

\section{Post-MGNREGA Situation}

MGNREGA was demand-driven employment generation scheme, a targeted jobs programme creating 'the employment of last resort', paying minimum wages (not exactly according to that notified under minimum wages act), the aim behind the scheme was to create a social floor. From the day the scheme was conceptualised, it has been highly controversial with many people arguing that it is going to be a big failure basically due to two main reasons: first, it will be a very difficult task to identify and create such a large number of 'productive work', it happened also and in a way, there is a reason to believe that while being successful in creating work it destroyed the 'work-culture', but we will not going to discuss it as it goes beyond the scope of this paper. And, second, it will be more profitable if we try to strengthen our secondary sector, and spend the money (Table 15) more wisely than spending on the labour going to create unimportant assets lacking durability also, and give them chance to soak up the extra labour force present in the agricultural sector. For MGNREGA, in a quest to create jobs government divorced the profitability and created an inelastic demand for labour, something which only a government can do (Minsky, 1986, p.308).

The MGNREGA wages were not only higher than the prevailing wages but were multiple times higher than the prevailing

Table 13: Prevailing Pre-MGNREGA Female Wages as Percentage of Male Wages in Different States

\begin{tabular}{|c|c|c|c|c|c|c|c|}
\hline State & $\begin{array}{c}\text { Andhra } \\
\text { Pradesh }\end{array}$ & Assam & Bihar & Gujarat & Haryana & Karnataka & Kerala \\
\hline Per centage & 76.01 & 51.33 & 58.23 & 54.32 & 40.37 & 56.83 & 50.08 \\
\hline State & $\begin{array}{c}\text { Madhya } \\
\text { Pradesh }\end{array}$ & Maharashtra & Orissa & $\begin{array}{c}\text { Rajas- } \\
\text { than }\end{array}$ & $\begin{array}{c}\text { Tamil } \\
\text { Nadu }\end{array}$ & $\begin{array}{c}\text { Uttar } \\
\text { Pradesh }\end{array}$ & $\begin{array}{c}\text { West } \\
\text { Bengal }\end{array}$ \\
\hline Per centage & 65.35 & 60.22 & 31.25 & 21.39 & 51.37 & 54.59 & 72.56 \\
\hline
\end{tabular}

Source: Calculated from Table 11. 
wages. For most of the States, except Gujarat, they were more than two times of the male labourers' wage and more than up to seven times of the female labourers' wage. The average female wage rate in the Rajasthan was as low as Rs. 9.45, whereas the MGNREGA wage for the State was Rs.73. This means a woman getting 10 days of work under MGNREGA earns an amount approximately equal to 78 days' work. In a way, it created a new reservation wage for the unskilled workers. In Gujarat, MGNREGA wages in 2006 were Rs. 50, which as Rs. 5.48 less than that of the prevailing wages, but Gujarat also witnessed the steepest rise in the wage rates in the coming years (Table 16). After leaving it Rs 50 only up to the financial year 2007-08, the Gujarat government made the wages Rs. 100 in 2008-09 and later Rs. 178, which means that there has been more than three-and-a-half fold rise in the MGNREGA wage rate.

All over India, the wages shot up, "during the eleventh five-year plan, nominal farm wages in India increased by 17.5 per cent per annum and real wages increased by 6.8 per cent per annum, registering the fastest growth" since 1991 (Gol). The real farm wages, which registered a growth of 3.7 per cent per annum during the 1990s, went down to 1.8 per cent in the pre-MGNREGA period. But once NREGA became operational, the growth rate shot up to 6.8 per cent from 2006-07 to 2011-12. The main source of the workforce in many sectors is the rural labour force which is willingly or unwillingly engaged in the agriculture.
For example, in 2005 when MGNREGA was planned, 71 per cent of the female employees and 46 per cent of the male employees were in the agriculture sector. So, the impact of this rise was felt everywhere.

Table 14: Labour Expenditure in MGNREGA

\begin{tabular}{|c|c|}
\hline Year & Labour expenditure (in million) \\
\hline $2006-07$ & $56,750.0$ \\
\hline $2007-08$ & $1,06,828.4$ \\
\hline $2008-09$ & $1,81,942.6$ \\
\hline $2009-10$ & $2,54,354.3$ \\
\hline $2010-11$ & $2,56,456.5$ \\
\hline $2011-12$ & $2,43,160.9$ \\
\hline $2012-13$ & $2,71,533.7$ \\
\hline $2013-14$ & $2,64,859.1$ \\
\hline $2014-15$ & $2.29,960.0$ \\
\hline $2015-16$ & $2,90,669.1$ \\
\hline $2016-17$ & $3,92,865.7$ \\
\hline
\end{tabular}

Source: MGNREGA public data portal.

MGNREGA has provided social security to 182 million beneficiaries (almost 15 per cent of India's total population), it proved that how with a "universal demand-driven programme like MGNREGA the government can actually influence the rural labour market indirectly through greater empowerment to the workers and increasing the bargaining power of the workers vis-à-vis their employers" (Saha and Verick, 2016). The studies conducted evaluating the impacts not only revealed a reduction in distressed migration to urban areas but even a temporary shortage of labour, those land-holders, who use to employ wage 
labour on their farm started complaining that the MGNREGA is creating a labour scarcity, a fact which even government accepted (Economic Times, 2013).

The programme brought global accolades as in global wage report 2014-15, the International Labour Organisation praised it for the rise in wages of low income groups noting "in some emerging and developing economies, raising the income of low-income groups has been achieved through direct employment programme (as in India and South Africa)" (ILO, 2015).

\section{MGNREGA and Women Participation}

In the situation where the various forms of exploitation along with the patriarchal mindset is dominated, the wage differences made the conditions very unfavourable for the women. In the period between 2004-05 and 201112 , the gap in wages of male-female casual labourers declined by nearly six percentage points between to 31 per cent (Bhattacharya and Deshpande, 2013). A paper based on the field research by Khera and Nayak (2009) has noted that the MGNREGA employment was considered attractive for the women because it promises to pay the statutory minimum wages. They noted that NREGA wages imply a substantial jump in the earning potential of women and as per their survey data, the average wage earned by women in private labour ranged from Rs. 47 to Rs. 58 whereas the NREGA earnings were INR 85 per day. For these women for whom there neither existed any other possible job in the locality, they cannot work on a faraway worksite as they are supposed to do household chores also, nor the option for migration as they face many social constraints MGNREGA was a revolution.

MGNREGA got a very positive response from the women. The most important reason, as mentioned above, was high women participation and the equality in payment which helped the women more than the men. In MGNREGA, the wages were not equal to the male wage rates but taking Rajasthan as an example it was more than seven times. So, it at once created a situation of equality, which in turn, made the way of women empowerment at least in the economic terms. But other than the wages, women like NREGA work because of various reasons, "Firstly, it is locally available. The Act provides that work is to be provided within five kilometres of the residence of a worker. Therefore, women's participation in the work has been feasible. Working at a distant place is difficult for women who happen to take the main responsibility of household chores. Secondly, there is less chance of exploitation. There is a statutory minimum wage, and hence wage earned in NREGA work is much more than the works under a private employer, more so in backward areas. The piece-rate wages and formation of small and mixed/solely women groups have given leverage to evolve their working norms to suit their conditions. Thirdly, there is regularity and predictability of working hours. As such, not only the members 
of the existing workers' group prefer NREGA work, but there is also the possibility of new entrants into the women workers group. Again, work is limited to eight hours a day, which is seldom expected in other works" (Dheeraja et al.). The reasons other than those mentioned above but play a very significant role is the job card because it gives a sense of working as a permanent labour on a government project, in other words, it makes the MGNREGA jobs respectable.

This increase in the wages and the sense of equality generated by the MGNREGA was rewarded heavily by the women who participated in large numbers. When we look at the women participation in the MGNREGA, the scheme looks more favourable. In spite of declining labour force participation rate of women (Table 12), their participation in MGNREGA constantly increased, both in terms of percentage as well as absolute numbers (Table 17). In 2006-07, MGNRGA created 3,578 lakh person-days for women which increased to 10,526 lakh person-days in 201112. The growth continued and in 2011-12, the percentage of person-days worked by the women comes out to be 47.47 per cent. In the next year, 2012-13, the percentage rose to 50.79 per cent, with 11,040 lakh person-days out of 21,735 person-days. In none of the year, the percentage share decreased - in the year 2016-17 it was 55.97 per cent (Table 17).

Table 15: Total Person-days Created/Worked by MGNREGA and Participation of Women

\begin{tabular}{|c|c|c|c|}
\hline Year & $\begin{array}{c}\text { Total person-days } \\
\text { worked (in lakh) }\end{array}$ & $\begin{array}{c}\text { Person-days created/ } \\
\text { worked for women (in lakh) }\end{array}$ & $\begin{array}{c}\text { Percentage of person- } \\
\text { days worked by women }\end{array}$ \\
\hline $2006-07$ & -- & 3,578 & -- \\
\hline $2007-08$ & -- & 5,927 & -- \\
\hline $2008-09$ & -- & 10,329 & -- \\
\hline $2009-10$ & -- & 13,557 & -- \\
\hline $2010-11$ & -- & 12,273 & -- \\
\hline $2011-12$ & 20,773 & $9,861^{*}$ & 57.47 \\
\hline $2012-13$ & 21,735 & $11,040^{*}$ & 52.44 \\
\hline $2013-14$ & 20,883 & $10,952^{*}$ & 54.46 \\
\hline $2014-15$ & 15,587 & $8,490^{*}$ & 54.90 \\
\hline $2015-16$ & 22,096 & $12,132^{*}$ & 55.97 \\
\hline $2016-17$ & 22,487 & $12,586^{*}$ & \\
\hline
\end{tabular}

*Number of days actually worked by women.

Source: MGNREGA public data portal. 


\section{Conclusion}

India had given voting rights to women just after Independence and we value equality so much that it finds a place in the Preamble of Indian Constitution. But the harsh reality is that even after 70 years of Independence and 68 years of adopting the Constitution, we are an unequal society with a number of hindrances present for the women and historically marginalised people. The expected Lewisian turn is too far to achieve in the short run. Finding employment for the huge workforce in secondary and tertiary sectors is going to be a herculean task, as it is not only the problem that enough jobs are not being created, there exist huge barriers of education and skill. Most of the rural workforce is either illiterate or with just primary education. Even though it is a proven fact that educating and making women economically well-off have many indirect benefits like bringing down the infant mortality rate, the condition of women is worse than that of the men. They lag far behind men in terms of economic participation and opportunities - in rural as well as urban areas. As a nation, we are lagging far behind other countries in making our women economically independent.
The participation of women is much higher in rural areas, especially in agriculture; but is also a fact that agriculture is one of the sectors with the least wages. With the increasing mechanisation of agriculture, the workers are being displaced and because of enough good jobs not being created, they engage themselves in whatever jobs they find in the non-farm sectors. For women, there exist substantial wage gaps even in the agricultural sector. Historical experiences suggest that wage difference cannot be addressed just with legislative and administrative ways. The wage differences continue to exist until we are not being able to provide employment guaranteeing equal wages. The policies should be aimed at reducing male-female wage differences and raising the overall wages, thereby resulting in reducing wage disparity and becoming an effective instrument for reducing poverty - these have been the lessons of MGNREGA. The impacts of MGNREGA have been different in different States depending upon the implementation in each of the State, block or whatever be the unit. But, everywhere it has been quite successful in providing wage equality, opportunity of participation in productive and gainful employment ensuring livelihood security and higher wages to the women in general, and that of marginalised sections in particular. 


\section{References}

ADB Briefs, "Female Labour Force Participation in Asia: Key Trends, Constraints and Opportunities", No. 71, October 2016; accessed from https://www.adb.org/publications/female-labour-forceparticipation-asiaaccessed at 8:47 pm, August 9, 2018.

Bhattacharya Pramit and Aishwarya Deshpande, "The Gender Divide in the Indian Labour Market", Livemint, Published: Mon, Nov 18 2013. 0601 PM IST; accessed from http://www.livemint.com/ Politics/zlQeewlbvuKrW6aZw5bHyl/The-gender-divide-in-the-Indian-labour-market.html, at 6.53 pm, January 28, 2018.

Chand Ramesh and Srivastava S K (2014), "Changes in the Rural Labour Market and their Implications for Agriculture", Economic and Political Weekly, March 8, 2014, Vol. 49, No. 10.

Da Corta and Venkateshwarlu, "Unfree Relations and the Feminisation of Agricultural Labour in Rural Labour Relations in India", Frank \& Cass

Das Pinaki (2012), "Trends of Rural Employment in India: Reflections from Recent NSS Data"; Vidyasagar University Journal of Economics, Vol. XVI, 2011-12.

Dev S. Mahendra (2016), “Economic Reforms, Poverty and Inequality”, WP-2016-009, Indira Gandhi Institute of Development Research, Mumbai, March 2016; accessed from http://www.igidr.ac.in/ pdf/publication/WP-2016-009.pdf, at 8:53 pm August 9, 2018.

C Dheeraja, N.V. Madhuri, Antaripa Daimari, Research Study on 'Factors Facilitating Participation of Women in Mahatma Gandhi NREGS," Research Report Series 98; National Institute of Rural Development, Ministry of Rural Development, Government of India; accessed from http://www. nird.org.in/nird_docs/rss/RS\%2098.pdf accessed at 8:57 pm August 9, 2018.

Dreze Jean and Reetika Khera,"TheBattle ofEmployment Guarantee",Frontline,Vol.26No.01:Jan.0316, 2009; accessed from https://www.frontline.in/static/html/fl2601/stories/20090116260100400. htm, at 08:58 pm August 9, 2018.

Economic Times (2013), "Temporary Labour Shortage Reported due to MGNREGA: Government", May 3, accessed from https://economictimes.indiatimes.com/news/politics-and-nation/ temporary-labour-shortage-reported-due-to-mgnrega-government/articleshow/19862911.cms, at August 9, 2018. 
Fei, John C H and Gustav Ranis (1975), "A Model of Growth and Employment in the Open Dualistic Economy: The Cases of Korea and Taiwan", Journal of Development Studies, 11(2): 32-63.

Ghose, A.K. (2015), "India Employment Report", Institute for Human Development, New Delhi. Gol, MGNREGA Public Data Portal, accessed at 1.10 pm, 25 January, 2018.

Gol, Labour Bureau (2011), Rural Labour Enquiry, Report on General Characteristics of Rural Labour Households, $61^{\text {st }}$ round of NSSO 2004-05, Ministry of Labour.

Gol, The Rural Labour Enquiry Report on General Characteristics of Rural Labour Households 2004-05, Ministry of Labour, Labour Bureau, Shimla / Chandigarh, 2011, p.17

Gulati Ashok, Surbhi Jain and Nidhi Satija; "Rising Farm Wages in India, The 'Pull' and 'Push'Factors", Commission for Agricultural Costs and Prices, Department of Agriculture \& Cooperation, Ministry of Agriculture, Government of India.

Held David (2015); Political Theory and Modern State, Rawat Publication, p.1

IAMR, Survey of Twenty Districts, Institute of Applied Manpower Research, Narela; http:// planningcommission.gov.in/reports/genrep/rep_NREGA_03-08-2009.pdf

ILO, Global Wage Report, 2014/15, International Labour Organization, Geneva; http://www.ilo. org/global/publications/books/WCMS_324678/lang--en/index.htm

ILO 2016; India Labour Market Update, ILO Country Office for India, July 2016; http://www.ilo. org/wcmsp5/groups/public/---asia/---ro-bangkok/---sro-new_delhi/documents/publication/ wcms_496510.pdf

ILO 2011, Issues in Labour Market Inequality and Women's Participation in India's NREGP Works, Sukti Dasgupta \& Ratna M.Sundram, Paper no. 98; http://www.lo.org/wcmsp5/groups/public/--dgreports/-integration/documents/publication/wcms_153042.pdf

ILO 2014, Women's Labour Force Participation in India: Why is it So Low? International Labour Organization, Geneva; http://www.ilo.org/wcmsp5/groups/public/---asia/---ro-bangkok/---sronew_delhi/documents/genericdocument/wcms_342357.pdf

Jha Praveen (2017), India's Industrial Structure and Policy: Challenges and Way Forward for a Progressive Trajectory, ILO, ISBN 978-922-130013. 
JP Morgan, (2011) 'Wages in Rural India Accelerated Sharply post-NREGA, Lahoti Rahul and Hema Swaminathan (2013), “Economic Growth and Female Labour Force Participation in India”, Working Paper No: 414, Indian Institute of Management, Bangalore.

Lanjouw, P., Shariff, A. (2004), "Rural Non-Farm Employment in India: Access, Incomes and Poverty Impact", Economic and Political Weekly, Vol. 39, No. 4

Mann Neelakshi and Jairam Ramesh, "Rising Farm Wages will Lift All Boats", The Hindu, 14 ${ }^{\text {th }}$ may 2013, accessed from https://www.thehindu.com/opinion/op-ed/rising-farm-wages-will-lift-allboats/article4712302.ece

Mehrotra Santosh, Gandhi Ankita, Saha Partha, Sahoo Bimal Kishore (2012), Joblessness and Informalization: Challenges to Inclusive Growth in India, IAMR Occasional Paper No. 9/2012, Institute of Applied Manpower Research, Planning Commission, Government of India, accessed from http://iamrindia.gov.in/writereaddata/UploadFile/Joblessness.pdf

Dr. Kulamani Padhi, Agricultural Labour in India - A Close Look, Orissa Review, February-March, 2007.

Papola T.S (2012), Social Exclusion and Discrimination in the Labour Market, Based on a lecture at the Commonwealth International Workshop- cum-Training Programme on Public Policy for Poverty Reduction Governance, Rationale, Intervention and Impacts, June 17-23 2012, Institute of Development Studies, Jaipur, June 22

Rodrik Dani 2015, Premature Deindustrialization, J Econ Growth (2016) 21:1-33

Saha Partha and Verick Sher, May 2016, State of Rural Labour Markets in India, ILO Asia-Pacific Working Paper Series, International Labour Organization; ILO DWT for South Asia and Country Office for India, ISBN: 9789221311881 (web pdf)

Saha, P., Rawal, V. (forthcoming). "Women's Employment in India: What do Recent NSS Surveys of Employment and Unemployment Show?", C P Chandrasekhar (ed.), "Essays in Honour of Utsa Patnaik", Tulika Publisher.

Sarkar, A. (2013). "Tractor Production and Sales in India, 1989-2009", Review of Agrarian Studies, Vol. 3, No.1

Sharma Alakh N. 2007, Flexibility, Employment and Labour Market Reforms in India, Working 
Paper No. 37, Institute for Human Development, New Delhi.

Sharma H.R., Economic Conditions of Agricultural Labour Households in 1990s: A State Level Analysis of Wage Earnings and Indebtedness

Sheila Bhalla (1999), Liberalisation, Rural Labour Markets and the Mobilisation of Farm Workers: The Haryana Story in an All-India Context, Rural Labour Relations in India, Frank \& Cass, p.38

Thorat Sukhdeo; Mahamallik, Motilal and Panth, Ananth (2003), Labour Market and Occupational Discrimination in Rural Areas, Indian Institute of Dalit Studies (IIDS), New Delhi

Labour Market Discrimination: Concept, Forms and Remedies in the Indian Situation, The Indian Journal of Labour Economics, Vol.51, No.1, 2008 pp.31-52

United Nations Development Programme, Human Development Report 2012, UNDP, New York Human Development Report 2015

Human Development Report 2016

Vaidyanathan, A. (1986), "Labour Use in Rural India: A Study of Spatial and Temporal Variation", Economic and Political Weekly, Vol. 21, No. 52.

Dr. Davuluri Venkateswarlu and Jacob Kalle (2012), "Wages of Inequality Wage Discrimination and Underpayment in Hybrid Seed Production in India; December 2012; Study commissioned by Fair Labour Association (FLA) and India Committee of the Netherlands (ICN). 